\title{
Yonsei Experience of 5000 Gasless Transaxillary Robotic Thyroidectomies
}

\author{
Sapana Bothra $^{1} \cdot$ Sabaretnam Mayilvaganan $^{1}$
}

Published online: 14 November 2017

(C) Société Internationale de Chirurgie 2017

We read with interest the article "Yonsei experience of 5000 gasless transaxillary Robotic Thyroidectomies" by Kim et al. [1]. We congratulate the authors on their huge experience of 5000 gasless transaxillary robotic thyroidectomies and their constant effort and passion to refine this art of transaxillary robotic thyroidectomy to attain acceptable norms of safe thyroid surgery $(<2 \%$ Hypoparathyroidism and $<2 \%$ RLN injury) [2]. This retrospective study analyzes the journey through 5000 thyroidectomies and we also agree with authors that prospective studies with large numbers and long period are difficult to conduct. We have few queries which shall interest to some future readers.

During the same period (October 2007 to May 2017) how many open thyroidectomies were performed, their indications and the cost difference between the two procedures? How was the period divided? Was this based on any factor such as the introduction of newer generation of robot, etc. Do their trainees find it difficult to adapt to transaxillary robotic thyroidectomy without open surgical experience? What factor contributed to surgery of 1367 patients in the second period consisting of only two months December 2011 and January 2012? In less than total thyroidectomy how much thyroid tissue was left behind?

Thank you for your comments on these issues.

\section{References}

1. Kim MJ, Nam KH, Lee SG, Choi JB, Kim TH, Lee CR, Lee J, Kang SW, Jeong JJ, Chung WY (2017) Yonsei experience of 5000 gasless transaxillary robotic thyroidectomies. World J Surg. https://doi.org/10.1007/s00268-017-4209-y

2. Marohn MR, LaCivita KA (1995) Evaluation of total/near-total thyroidectomy in a short-stay hospitalization: safe and costeffective. Surgery 118(6):943-948
Sabaretnam Mayilvaganan drretnam@gmail.com

1 Department of Endocrine and Breast Surgery, Sanjay Gandhi Postgraduate Institute of Medical Sciences, Lucknow, India 